\title{
Two new anthraquinones from the soil fungus Penicillium purpurogenum SC0070
}

\author{
Jinghua Xue, Ying Fu, Ping Wu, Liangxiong Xu, Riming Huang, Xiaoyi Wei and Hanxiang Li
}

The Journal of Antibiotics (2015) 68, 598-599; doi:10.1038/ja.2015.35; published online 15 April 2015

The genus Penicillium comprises $>300$ species, ${ }^{1}$ which produce a variety of novel bioactive compounds. Well-known drugs from this genus are penicillin antibiotics produced by $P$. chrysogenum ${ }^{2}$ and the antifungal metabolite griseofulvin produced by $P$. griseofulvum ${ }^{3}$ and $P$. patulum. ${ }^{4}$ As a part of an ongoing program aimed at exploring antibacterial natural products produced by the fungi obtained from South China, ${ }^{5-7}$ we have investigated the bioactive compounds of the fungus $P$. purpurogenum SC0070 isolated from a soil sample collected under a palm grove. We recently reported that cultures of $P$. purpurogenum SC0070 produced a rearranged sterol with antiinflammatory and cytotoxic properties, penicillitone, and a new related sterol, penicillisterol. ${ }^{8}$ In this paper, continuing chemical investigation of the fungus has resulted in the isolation of two new anthraquinones, penipurdin A (1) and B (2), together with a known analog, questin (3). Details of the isolation, structure elucidation and biological activities of the compounds are presented here.

Solid-substrate fermentation cultures of Aspergillus versicolor SC0070 grown on wheat grains were extracted with $95 \% \mathrm{EtOH}$, and the resultant extract was sequentially partitioned with petroleum ether, $\mathrm{CHCl}_{3}, \mathrm{EtOAc}$ and $n$-BuOH. The $\mathrm{CHCl}_{3}$ and EtOAc extract were fractionated by silica gel column chromatography, followed by Sephadex LH-20 and/or reversed-phase HPLC, to afford compounds 1-3 (Figure 1).

Penipurdin A (1) was obtained as an amorphous organge-red solid

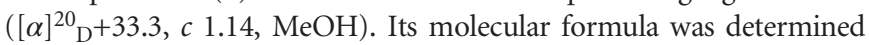
as $\mathrm{C}_{18} \mathrm{H}_{16} \mathrm{O}_{6}$ from HRESIMS (found $\mathrm{m} / \mathrm{z} 329.1022[\mathrm{M}+\mathrm{H}]^{+}$, calcd 329.1020) and NMR data. The ${ }^{1} \mathrm{H}$ and ${ }^{13} \mathrm{C}$ NMR spectra of 1 (Table 1) revealed the presence of two methyl groups including one $O$-methyl, one methylene, one $O$-methine, 12 aromatic carbons (four of which were protonated) and two conjugated ketone carbonyl groups $\left(\delta_{\mathrm{C}} 182.6\right.$ and 186.6). These spectroscopic features suggested that $\mathbf{1}$ has the same anthraquinone skeleton as found in questin $(3)^{9}$ that was isolated from the crude extract of the same fungus. The substituents and their location on the anthraquinone ring were established by the analysis of the ${ }^{1} \mathrm{H}-{ }^{1} \mathrm{H}$ COSY, HMBC and NOESY spectra of 1 (Figure 2a). The chelated hydroxyl group at $\delta_{\mathrm{H}} 13.22$ exhibited HMBC correlations to C-1, C-2 and C-9a, establishing the location of this hydroxyl group at $\mathrm{C}-1 .{ }^{1} \mathrm{H}-{ }^{1} \mathrm{H}$ COSY connectivities of $\mathrm{H}_{2}-1^{\prime}$ to $\mathrm{H}-2^{\prime}\left(\delta_{\mathrm{H}} 3.88\right)$ and $\mathrm{H}-2$ ' to $\mathrm{H}_{3}-3^{\prime}$ suggested the presence of a 2-hydroxypropyl group. $\mathrm{HMBC}$ correlations of $\mathrm{H}_{2}-1$ ' to $\mathrm{C}-2, \mathrm{C}-3$ and $\mathrm{C}-4$ indicated that the 2-hydroxypropyl group was attached at C-1. For the left portion of 1 , a pair of protons $\left[\delta_{\mathrm{H}} 7.21\right.$ and 6.84 (each $1 \mathrm{H}, \mathrm{d}$, $J=2.0 \mathrm{~Hz}$ )] were located at C-5 and C-7, respectively, on the basis of HMBC correlations from $\mathrm{H}-5\left(\delta_{\mathrm{H}} 7.21\right)$ to the carbonyl carbon C-10 $\left(\delta_{\mathrm{C}}\right.$ 182.6). The methoxyl group at $\delta_{\mathrm{H}} 3.90$ was placed on C-8 based on its correlation with $\mathrm{H}-7\left(\delta_{\mathrm{H}} 6.84\right)$ in the NOESY spectrum. Consequently, the remaining phenolic hydroxyl group was assigned to C-6, which was further supported by the chemical shift for C-6 at $\delta_{\mathrm{C}}$ 164.6. The absolute configuration at C-2' of 1 was determined by the modified Mosher method. ${ }^{10}$ Treatment of 1 with (S)-MPA (methoxyphenylacetic acid) or (R)-MPA in the presence of DMAP (4-dimethylaminopyridine) afforded the $(S)$-MPA ester or $(R)$-MPA ester, respectively. The values of $\Delta \delta^{R, S}\left(\delta_{R}-\delta_{S}\right)$ in the ${ }^{1} \mathrm{H}$ NMR (Figure $2 \mathrm{~b}$ ) spectra suggested that the absolute configuration at C-2' of 1 was $S$. Therefore, the structure of $\mathbf{1}$ was proposed as shown in Figure 1, and named penipurdin A.

Penipurdin B (2) was isolated as a yellow powder. High-resolution ESIMS showed a peak at $\mathrm{m} / \mathrm{z} 299.0916[\mathrm{M}+\mathrm{H}]^{+}(\mathrm{m} / \mathrm{z}$ calcd 299.0914)<smiles>[R][R]#[R]#P</smiles>

Figure 1 Structures of compounds $1-3$ isolated from $P$. purpurogenum SC0070.

Key Laboratory of Plant Resources Conservation and Sustainable Utilization/Guangdong Provincial Key Laboratory of Applied Botany, South China Botanical Garden, Chinese Academy of Sciences, Guangzhou, China

Correspondence: Dr H Li, Key Laboratory of Plant Resources Conservation and Sustainable Utilization/Guangdong Provincial Key Laboratory of Applied Botany, South China Botanical Garden, Chinese Academy of Sciences, Guangzhou 510650, China.

E-mail: lihanxiang@scbg.ac.cn

Received 18 December 2014; revised 9 March 2015; accepted 16 March 2015; published online 15 April 2015 
Table $1{ }^{1} \mathrm{H}$ - and ${ }^{13} \mathrm{C}$-NMR data of Penipurdin A (1) and $\mathrm{B}(2)$

\begin{tabular}{|c|c|c|c|c|}
\hline \multirow[b]{2}{*}{ No. } & \multicolumn{2}{|c|}{ Penipurdin A $(\mathbf{1})^{\mathrm{a}}$} & \multicolumn{2}{|c|}{ Penipurdin $B(2)^{\mathrm{b}}$} \\
\hline & $\delta_{C}$, type & $\delta_{H}$, mult. (J in Hz) & $\delta_{C}$, type & $\delta_{H}$, mult. (J in $\left.\mathrm{Hz}\right)$ \\
\hline 1 & $161.6, \mathrm{C}$ & & $163.2, \mathrm{C}$ & \\
\hline 2 & 125.0, $\mathrm{CH}$ & $7.14, \mathrm{~d}(1.2)$ & $125.6, \mathrm{CH}$ & $7.27, \mathrm{~d}(1.2)$ \\
\hline 3 & $148.8, \mathrm{C}$ & & $152.4, \mathrm{C}$ & \\
\hline 4 & 119.9, CH & $7.48, \mathrm{~d}(1.2)$ & $122.2, \mathrm{CH}$ & $7.72, \mathrm{~d}(1.2)$ \\
\hline $4 a$ & $131.9, \mathrm{C}$ & & $134.1, \mathrm{C}$ & \\
\hline 5 & 107.2, CH & $7.21, \mathrm{~d}(2.0)$ & $120.3, \mathrm{CH}$ & 7.80, dd $(8.2,1.4)$ \\
\hline 6 & $164.6, \mathrm{C}$ & & $138.3, \mathrm{CH}$ & $7.83, \mathrm{t}(8.2)$ \\
\hline 7 & 105.1, CH & $6.84, d(2.0)$ & $125.1, \mathrm{CH}$ & 7.36, dd $(8.2,1.4)$ \\
\hline 8 & $163.8, \mathrm{C}$ & & 163.3, C & \\
\hline $8 a$ & $112.9, \mathrm{C}$ & & $116.9, \mathrm{C}$ & \\
\hline 9 & 186.6, C & & $193.8, \mathrm{C}$ & \\
\hline $9 a$ & $114.8, \mathrm{C}$ & & $115.0, \mathrm{C}$ & \\
\hline 10 & 182.6, C & & $182.3, \mathrm{C}$ & \\
\hline $10 a$ & $137.1, \mathrm{C}$ & & $134.8, \mathrm{C}$ & \\
\hline $1^{\prime}$ & $45.1, \mathrm{CH}_{2}$ & $\begin{array}{l}2.68, \text { dd }(12.9,7.2) \\
2.74, \text { dd }(12.9,5.2)\end{array}$ & $46.5, \mathrm{CH}_{2}$ & $\begin{array}{l}2.84 \text {, dd }(13.4,7.7) \\
2.91 \text {, dd }(13.4,4.8)\end{array}$ \\
\hline $2^{\prime}$ & $66.8, \mathrm{CH}$ & 3.88 , overlapped & $68.2, \mathrm{CH}$ & $4.11, \mathrm{~m}$ \\
\hline $3^{\prime}$ & $23.5, \mathrm{CH}_{3}$ & $1.09, \mathrm{~d}(6.2)$ & $23.9, \mathrm{CH}_{3}$ & $1.23, \mathrm{~d}(6.2)$ \\
\hline 2'-OH & & 4.70, brs & & $3.86, d(5.0)$ \\
\hline $1-\mathrm{OH}$ & & $13.22, \mathrm{~s}$ & & $12.06^{c}$ \\
\hline $6-\mathrm{OH}$ & & 11.27, brs & & \\
\hline 8-OMe & $56.5, \mathrm{CH}_{3}$ & $3.90, \mathrm{~s}$ & & \\
\hline $8-\mathrm{OH}$ & & & & $11.95^{c}$ \\
\hline
\end{tabular}

Abbreviation: No, number.

an DMSO- $d_{6}$.

bln actone- $d_{6}$.

These assignments are interchangeable.

corresponding to the molecular formula $\mathrm{C}_{17} \mathrm{H}_{15} \mathrm{O}_{5}$. The ${ }^{1} \mathrm{H}$ and ${ }^{13} \mathrm{C}$ NMR data of 2 were greatly similar to those of $\mathbf{1}$ except for the absence of the methoxyl (8-OMe, 1) and phenolic hydroxyl (6-OH, 1) groups, which were replaced by a chelated hydroxyl group and an aromatic proton, respectively. The gross structure of $\mathbf{2}$ was further confirmed by COSY and HMBC experiments and the $S$ configuration at C-2' was assigned by comparison of the sign of the optical rotation value of $2(+14.2)$ with that of penipurdin $\mathrm{A}(\mathbf{1} ;+33.3)$.

The known compound $\mathbf{3}$ was identified as questin by comparison of its NMR and MS data with those reported. ${ }^{9}$

The cytotoxicities of compounds $\mathbf{1}, \mathbf{2}$ and $\mathbf{3}$ were evaluated in vitro against the A549, HepG2 and Hela cell lines by MTT method. ${ }^{11}$ Compound 2 exhibited cytotoxic activity with $\mathrm{IC}_{50}$ values of 74.7, 3.9

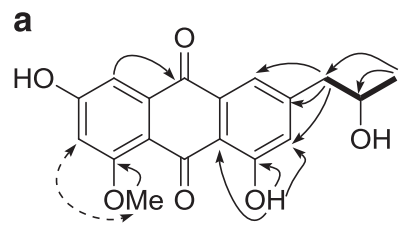<smiles>COc1cc(O)cc2c1C(=O)c1c(O)cc([C@H](C)O)cc1C2=O</smiles>

Figure 2 (a) Key $\mathrm{HMBC}$ (solid arrows), ${ }^{1} \mathrm{H}-{ }^{1} \mathrm{H}$ COSY (bond lines) and NOESEY (dashed arrow) correlations of 1 . (b) Observed chemical shift differences $\left(\Delta \delta=\delta_{\mathrm{R}}-\delta_{\mathrm{S}}\right.$, p.p.m., $\left.400 \mathrm{MHz}\right)$ for the $(R)$ - and (S)-MPA esters of 1 .

and $15.7 \mu \mathrm{M}$, respectively. The $\mathrm{IC}_{50}$ values of compound 3 were 39.5 , 6.2 and $14.9 \mu \mathrm{M}$, respectively. Compound 1 showed no cytotoxic activity to the three tested cell lines.

\section{ACKNOWLEDGEMENTS}

We thank Ai-Jun Sun, South China Sea Institute of Oceanology, Chinese Academy of Sciences, for the measurement of HRESIMS. This study was supported by grant from the National Natural Science Foundation of China (no. 81172942).

1 Kirk, P. M., Cannon, P. F., Minter, D. \& Stalpers, J. A. Dictionary of the Fungi 505, CABI: Europe-UK, (2008)

2 Martín, J. F. Molecular control of expression of penicillin biosynthesis genes in fungi: regulatory proteins interact with a bidirectional promoter region. J. Bacteriol. 182, 2355-2362 (2000).

3 Grove, J. F., MacMillan, J., Mulholland, T. P. C. \& Rogers, M. A. T. Griseofulvin. Part III. The structures of the oxidation products $\mathrm{C}_{9} \mathrm{H}_{9} \mathrm{O}_{5} \mathrm{Cl}$ and $\mathrm{C}_{14} \mathrm{H}_{15} \mathrm{O}_{7} \mathrm{Cl}$. J. Chem. Soc. 27, 3949-3958 (1952).

4 Broadbent, D., Mabelis, R. P. \& Spencer, H. 3,6,8-Trihydroxy-1-methylxanthone-an antibacterial metabolite from Pencillium patulum. Phytochemistry 14, 2082-2083 (1975).

5 Feng, N. et al. Two new antifungal alkaloids produced by Streptoverticillium morookaense. J. Antibiot. 60, 179-183 (2007).

6 Zhang, H. Y. et al. Polyoxygenated methyl cyclohexanoids from a terrestrial ampelomyces fungus. J. Nat. Prod. 72, 265-269 (2009).

7 Xu, L. X., He, Z. X., Xue, J. H., Chen, X. P. \& Wei, X. Y. $\beta$-resorcylic acid lactones from a Paecilomyces fungus. J. Nat. Prod. 73, 885-889 (2010).

8 Xue, J. H., Wu, P., Xu, L. X. \& Wei, X. Y. Penicillitone, a potent in vitro antiinflammatory and cytotoxic rearranged sterol with an unusual tetracycle core produced by Penicillium purpurogenum. Org. Lett. 16, 1518-1521 (2014).

9 Li, D.L., Li, X. M. \& Wang, B. G. Natural anthraquinone derivatives from a marine mangrove plant-derived endophytic fungus Eurotium rubrum: structural elucidation and DPPH radical scavenging activity. J. Microbiol. Biotechnol. 19, 675-680 (2009).

10 Yin, Y. Q., Huang, X. F., Kong, L. Y. \& Niwa, M. Three new pentasaccharide resin glycosides from the roots of sweet potato (Ipomoea batatas). Chem. Pharm. Bull. 56, 1670-1674 (2008).

11 Mosmann, T. Rapid colorimetric assay for cellular growth and survival: application to proliferation and cytotoxicity assays. J. Immunol. Methods 65, 55-63 (1983).

Supplementary Information accompanies the paper on The Journal of Antibiotics website (http://www.nature.com/ja) 